\title{
In vitro regeneration of bulblet using two and four bulb-scales explants of summer snowflake (Leucojum aestivum L.)
}

\author{
Masoumeh Abedinimazraeh $^{1 *}$ (1), Sepideh Kalatehjari ${ }^{1}$ (1)
}

${ }^{1}$ Islamic Azad University, Science and Research Branch, Faculty of Engineering, Department of Agricultural Engineering, Tehran, Iran.

\begin{abstract}
Leucojum aestivum is a valuable and endangered plant species with bulb scales best suited as explants in micropropagation. In the current study, its micropropagation was investigated by using two different explants and various concentrations and combinations of plant growth regulators (PGRs). Bulbs were first disinfected with benomyl ${ }^{\circledR}$ for 5 hours. After meeting the chilling requirements, two-scale and four-scale explants were provided for direct and indirect organogenesis. Explants were exposed to hot water, $70 \%$ ethanol and 2.5\% sodium hypochlorite for further disinfestation. Four-scale explants were treated with different concentrations and combinations of naphthaleneacetic acid (NAA), 6-benzyladenine (BA), and kinetin (Kin) for bulblet regeneration. For callogenesis, $0.5 \mathrm{mg} \mathrm{L}^{-1}$ of BA combined with 1, 2, 3, 4, 5 or $6 \mathrm{mg} \mathrm{L}^{-1}$ of 2,4-dichlorophenoxyacetic acid (2,4-D) were applied. Regarding two-scale explants, different combinations and concentrations of BA, Indole-3-butyric acid (IBA) and NAA were used for bulblet induction, and various combinations of Indoleacetic acid (IAA), NAA, 2, 4-D and BA were used for callus induction. None of the two-scale explants responded to the bulblet regeneration and callus induction media. Unlike, four-scale explants regenerated bulblets and roots in the control medium and MS media enriched with different PGRs. Callus was generated on MS medium supplemented with 2,4-D and BA, and indirect regeneration was observed in some cases. On the control medium, the regenerated roots had a natural form, but in PGRs-rich media, they were deformed. Regarding the regeneration percentage, bulblet number and length and root length, no significant differences were found between the control and the best PGR-treatment in each case. Therefore, it seems logical suggesting not to use PGRs, which will considerably reduce the costs at large-scale production.
\end{abstract}

Keywords: Amaryllidaceae, bulblet regeneration, callus induction, plant growth regulators.

\section{Resumo \\ Regeneração in vitro de bulbilhos usando explantes de duas e quatro escamas de floco-de-neve-de-verão (Leucojum aestivum $\mathrm{L}$.)}

Leucojum aestivum é uma espécie valiosa e ameaçada de extinção com escamas de bulbo mais adequadas como explantes em micropropagação. No presente estudo, a micropropagação foi investigada utilizando dois explantes diferentes e várias concentrações e combinações de reguladores de crescimento de plantas (RCPs). Os bulbos foram primeiro desinfetados com benomyl ${ }^{\circledR}$ por 5 horas. Após atender aos requisitos de resfriamento, explantes de duas e quatro escalas foram fornecidos para organogênese direta e indireta. Os explantes foram expostos a água quente, etanol 70\% e hipoclorito de sódio 2,5\% para posterior desinfestação. Explantes de quatro escalas foram tratados com diferentes concentrações e combinações de ácido naftalenoacético (NAA), 6-benziladenina (BA) e cinetina (Kin) para a regeneração dos bulbilhos. Para calogênese, foram aplicados $0,5 \mathrm{mg} \mathrm{L}^{-1}$ de BA combinado com 1, 2, 3, 4, 5 ou $6 \mathrm{mg} \mathrm{L}^{-1}$ de ácido 2,4-diclorofenoxiacético (2,4-D). Em relação aos explantes de duas escalas, diferentes combinações e concentrações de BA, ácido indol-3-butírico (IBA) e NAA foram usadas para indução de bulbilhos, e várias combinações de ácido indolacético (IAA), NAA, 2, 4-D e BA foram usados para indução de calo. Nenhum dos explantes em duas escalas respondeu à regeneração bulbilhos e aos meios de indução de calo. Ao contrário, explantes em quatro escalas regeneraram bulbilhos e raízes no meio de controle e meio MS enriquecido com diferentes RCPs. Calos foram gerados em meio MS suplementado com 2,4-D e BA, e regeneração indireta foi observada em alguns casos. No meio de controle, as raízes regeneradas tinham uma forma natural, mas em meio rico em RCPs, eram deformadas. Com relação à porcentagem de regeneração, número e comprimento de bulbilhos e comprimento de raiz, não foram encontradas diferenças significativas entre o controle e o melhor tratamento PGR em cada caso. Portanto, parece lógico sugerir a não utilização de RCPs, o que reduzirá consideravelmente os custos de produção em larga escala. Palavras-chave: Amaryllidaceae, regeneração de bulbilhos, indução de calo, reguladores de crescimento de plantas.

*Corresponding author: abedini24@gmail.com 


\section{Introduction}

Nowadays, numerous species are in danger of extinction in their natural habitats. Leucojum aestivum L., popularly known as summer snowflake, is an example of valuable plants which, despite its extremely high industrial potential, has received little attention regarding its protection and propagation (Kohut et al., 2007). During the past three decades, many natural L. aestivum habitats have fallen under threat due to the increasing demand by the pharmaceutical companies (Ivanov et al., 2019), while Ek1c1 (2017) claimed that this plant species has the potential for an alternative tourism type, i.e. flora tourism, due to its visual impacts on the landscape. Member of the Amaryllidaceae family, L. aestivum is a perennial bulbous plant distributed in various countries, including Czechoslovakia, Ireland, Turkey and Iran. This plant species is found from east to the west of Iran and also south of the Caspian coastal lowlands and north of Iran (Bakian et al., 2020). It is also widely found in the temperate zone in the world, distributed between the sea level and $1100 \mathrm{~m}$ in wetland and damp areas, such as swamps (Al-Faris et al., 2019). Spring flowering geophytes of the Amaryllidoideae such as L. aestivum have pronounced value as ornamental species (Crişan et al., 2019, Caruso et al., 2020). They have been planted in European gardens since the distant past (Caruso et al., 2020). Summer snowflake as the other Amaryllidoideae plant species has a high potential for adaptation (Torras et al., 2017). Because of its attractive flowers, L. aestivum is planted in landscapes, lakes or pools, rock gardens, borders with shrubs and trees (Hundur et al., 2018). Moreover, this medical species is particularly valuable both in medicine and pharmacy (Cherneva and Dimitrova, 2016) due to alkaloid production, as well as the other plants belonging to the Amaryllidaceae family (Reis et al., 2019).

It is feasible to propagate L. aestivum sexually (seed) or asexually (bulb division); however, sexual propagation takes five years or even more from seed to flowering (Kahraman and Akçal, 2016). On the other hand, the production rates of bulbs and corms, especially in plants belonging to the Iridaceae, Liliaceae, and Amaryllidaceae is low in situ and time consuming (Gheisari and Miri, 2017). Furthermore, scale rottenness is a considerable factor leading to the loss of a wide number of scales during propagation (Kharrazi et al., 2017) and also overharvesting has resulted in depletions of wild Amaryllidaceae populations (Saliba et al., 2016).

In vitro organ culture is considered as an alternative method for the conservation of endangered plant species. A single explant can be multiplied into numerous plants on a year round in relatively short period of time under controlled conditions, regardless of the weather conditions and season (Oseni et al., 2018). Species that naturally generate bulbs can be induced for in vitro bulb formation. In vitro bulbs can be transplanted or in vitro subcultured (Ptak, 2014).

Based on the reports in many bulbous species, axillary meristems successfully proliferate from the tissue attached to the base of bulb scales (Khonakdari et al., 2020). In the Amaryllidaceae family usually, twin scales explants consisted of two adjacent scales that are attached to a segment of basal plate tissue, have been successfully used in bulblet regeneration of several species (Babashpour-Asl et al., 2016), such as L. aestivum (Bogdanova et al. 2009). It has been claimed that twinscale and tri-scale propagation methods may allow rapid and cost effective way of plant production (Priyadharshini et al., 2020). Auxins and cytokinins play major roles by either blocking or stimulating outgrowth, respectively (Shahin et al, 2018). It has been reported that different combinations of these PGRs have the potential of callus induction or micropropagation in this plant family (Resetár et al., 2017). Ivanov et al. (2011) used $1.15 \mathrm{mg} \mathrm{L}^{-1} \mathrm{NAA}$ and $2 \mathrm{mg} \mathrm{L}^{-1} \mathrm{BA}$ for callus induction in L. aestivum plant. El Tahchy et al. (2011) employed different combinations and concentrations of 2, 4-D, BA, sucrose, and activated charcoal for induction of callus from leaves. Among the commercially available cytokinins, BA has been used more frequently, regarding to its low price and high efficacy in the promotion of in vitro regeneration in various plant species (Tubić et al., 2016).

During in vitro propagation, the exudation of phenols in Amaryllidaceae species often inhibits regeneration resulting in reduced growth or even tissue death. As a result, researchers are constantly searching for procedures to enhance the regeneration and proliferation of Amaryllidacae species (Naidoo et al., 2017).

Since preserving native plants is considerably important, this species can be produced commercially via tissue culture techniques and prevent its extinction by preserving genetic resources. Moreover, the first stage of any further breeding program is propagation and mass production of this plant. Two-scale explant is frequently used in micropropagation of L. aestivum, while four-scale explants have been studied rarely. Therefore, in the current study, we aimed at investigating the feasibility of direct and indirect micropropagation of summer snowflake using two-scale and four-scale explants and various PGRconcentrations and combinations.

\section{Material and Methods}

\section{Preparation of mother plants}

L. aestivum plants were transferred to Tehran, Iran after collection from their natural habitat in Anzali wetland (3746 $\left.89^{\prime \prime} \mathrm{N}, 49^{\circ} 35^{\prime} 37^{\prime \prime} \mathrm{E}\right)$ in April 2018. At that time, plants possessed leaves and flowers and were cultivated in pots, in order to provide explants, they were gradually transferred to Razi Laboratory Complex of Islamic Azad University, Science and Research Branch in Tehran.

In the laboratory, roots, leaves and old and dry scales were first dissected from the bulbs; afterward, bulbs were surface sterilized with $50 \%$ benomyl ${ }^{\circledR}$ for 5 hours. In order to break dormancy and meet the chilling requirements, they were placed in the fridge at 3 for five weeks.

\section{Explants preparation}

Before culture, bulbs were cut into 2 or 4 -scale pieces attached to the basal plate. Due to severe problems in 
disinfecting bulbs and their high contamination, based on our preliminary experiments, a method with the least damage to explants was employed. First, explants were rinsed for an hour under running tap water; subsequently, they were treated in the water bath at $52{ }^{\circ} \mathrm{C}$ for one hour. For surface disinfestation, $70 \%$ ethanol and $2.5 \%$ sodium hypochlorite were used for 10 and 15 minutes, respectively, and ultimately, they were rinsed thrice with sterilized distilled water.

\section{Culture Media preparation}

In this research, the MS basal medium (Murashige and Skoog, 1962) was used for cultivation. First, desired amounts of various plant growth regulators were added to the media, followed by $30 \mathrm{~g} \mathrm{~L}^{-1}$ sucrose. Finally, the solution's $\mathrm{pH}$ value was adjusted to 5.6-5.8, and $6 \mathrm{~g} \mathrm{~L}^{-1}$ of agar was added to the media. After autoclaving (at $121^{\circ} \mathrm{C}$ and pressure of $1.2 \mathrm{~atm}$ for $20 \mathrm{~min}$ ) they were distributed in tissue culture jars. After inoculating the explants on the media containing various PGR-treatments, they were maintained in a growth chamber at $25 \pm 1{ }^{\circ} \mathrm{C}$ with $16 \mathrm{~h}$ photoperiod during approximately a year.

PGRs combinations for bulblet regeneration and callus induction from four-scale explants

According to Table 1, for regeneration of bulblets from four bulb-scales explants of $L$. aestivum, MS medium was used in 10 PGR-combinations. Each replication included two four-scale explants attached to the basal plate. MS medium PGR-free was considered as a control. Explants were subcultured twice, each time after 30-45 days of culture, and the regeneration rate, number, and length of the regenerated bulblets, root regeneration percentage, number of the roots and their lengths were noted in the last subculture. Afterwards, for callus induction, MS medium was used in 6 PGRs combinations with two four-scale explants in each replication. Explants were subcultured after two months and the second subculture was carried out two months later and callus induction percentage and size were registered. Visual observations of cultures indicated that different amounts of callus were regenerated on the explants in various media treatments, which were assessed by scores between 0 (no callus formation) and 5 (profuse) (Hazeena and Sulekha, 2008).

PGRs combinations for bulblet regeneration and callus induction from two-scale explants

For bulblet regeneration and callus induction from two bulb-scale explants of L. aestivum, MS medium and PGRs combinations were used according to Table 2.

Table 1. Plant growth regulators treatments for bulblet regeneration and callus induction from four-scale explants

\begin{tabular}{|c|c|c|c|}
\hline \multicolumn{2}{|c|}{ PGRs treatments for bulblet regeneration } & \multicolumn{2}{|c|}{ PGRs treatments for callus induction } \\
\hline PGRs combinations & $\begin{array}{l}\text { Concentration } \\
\quad\left(\mathrm{mg} \mathrm{L}^{-1}\right)\end{array}$ & PGRs combinations & $\begin{array}{c}\text { Concentration } \\
\left(\mathrm{mg} \mathrm{L}^{-1}\right)\end{array}$ \\
\hline Control & 0 & 0 & 0 \\
\hline $\mathrm{BA}+\mathrm{NAA}$ & $0.5+0.1$ & $\mathrm{BA}+2,4-\mathrm{D}$ & $0.5+1$ \\
\hline $\mathrm{BA}+\mathrm{NAA}$ & $0.5+0.5$ & $\mathrm{BA}+2,4-\mathrm{D}$ & $0.5+2$ \\
\hline $\mathrm{BA}+\mathrm{NAA}$ & $0.5+1$ & $\mathrm{BA}+2,4-\mathrm{D}$ & $0.5+3$ \\
\hline $\mathrm{BA}+\mathrm{NAA}$ & $1+0.1$ & $\mathrm{BA}+2,4-\mathrm{D}$ & $0.5+4$ \\
\hline $\mathrm{BA}+\mathrm{NAA}$ & $1+0.5$ & $\mathrm{BA}+2,4-\mathrm{D}$ & $0.5+5$ \\
\hline $\mathrm{BA}+\mathrm{NAA}$ & $1+1$ & $\mathrm{BA}+2,4-\mathrm{D}$ & $0.5+6$ \\
\hline $\mathrm{BA}+\mathrm{NAA}$ & $2+0.2$ & & \\
\hline $\mathrm{BA}+\mathrm{NAA}$ & $2+0.15$ & & \\
\hline $\mathrm{BA}+\mathrm{NAA}+$ kin & $1+1+1$ & & \\
\hline $\mathrm{BA}+\mathrm{kin}$ & $1+1$ & & \\
\hline
\end{tabular}


Table 2. PGRs treatments for bulblet regeneration and callus induction from two-scale explants

\begin{tabular}{|c|c|c|c|}
\hline \multicolumn{2}{|c|}{ PGRs treatments for bulblet regeneration } & \multicolumn{2}{|c|}{ PGRs treatments for callus induction } \\
\hline PGRs combinations & $\begin{array}{c}\text { Concentration (mg } \\
\left.\mathbf{L}^{-1}\right)\end{array}$ & PGRs combinations & $\begin{array}{c}\text { Concentration (mg } \\
\left.\mathbf{L}^{-1}\right)\end{array}$ \\
\hline Control & 0 & 0 & 0 \\
\hline $\mathrm{BA}+\mathrm{NAA}$ & $0.5+0.1$ & $\mathrm{BA}+2,4-\mathrm{D}$ & $0.5+0.5$ \\
\hline $\mathrm{BA}+\mathrm{NAA}$ & $0.5+0.5$ & $\mathrm{BA}+2,4-\mathrm{D}$ & $0.5+1$ \\
\hline $\mathrm{BA}+\mathrm{NAA}$ & $0.5+1$ & $\mathrm{BA}+2,4-\mathrm{D}$ & $0.5+2$ \\
\hline $\mathrm{BA}+\mathrm{NAA}$ & $1+0.1$ & $\mathrm{BA}+2,4-\mathrm{D}$ & $0+0.5$ \\
\hline $\mathrm{BA}+\mathrm{NAA}$ & $1+0.5$ & $\mathrm{BA}+2,4-\mathrm{D}$ & $0+1$ \\
\hline $\mathrm{BA}+\mathrm{NAA}$ & $1+1$ & $\mathrm{BA}+2,4-\mathrm{D}$ & $0+2$ \\
\hline $\mathrm{BA}+\mathrm{NAA}$ & $2+1$ & $\mathrm{BA}+\mathrm{IAA}$ & $0.5+1$ \\
\hline $\mathrm{BA}+\mathrm{NAA}$ & $2+0.5$ & $\mathrm{BA}+\mathrm{IAA}$ & $0.5+2$ \\
\hline $\mathrm{BA}+\mathrm{NAA}$ & $2+1$ & $\mathrm{BA}+\mathrm{IAA}$ & $0.5+3$ \\
\hline $\mathrm{BA}+\mathrm{IBA}$ & $0.5+0.1$ & $\mathrm{BA}+\mathrm{IAA}$ & $0+1$ \\
\hline $\mathrm{BA}+\mathrm{IBA}$ & $0.5+0.5$ & $\mathrm{BA}+\mathrm{IAA}$ & $0+2$ \\
\hline $\mathrm{BA}+\mathrm{IBA}$ & $0.5+1$ & $\mathrm{BA}+\mathrm{IAA}$ & $0+3$ \\
\hline $\mathrm{BA}+\mathrm{IBA}$ & $1+0.5$ & $\mathrm{BA}+\mathrm{NAA}$ & $0.5+0.5$ \\
\hline $\mathrm{BA}+\mathrm{IBA}$ & $1+1$ & $\mathrm{BA}+\mathrm{NAA}$ & $0.5+1$ \\
\hline $\mathrm{BA}+\mathrm{IBA}$ & $2+0.1$ & $\mathrm{BA}+\mathrm{NAA}$ & $0.5+2$ \\
\hline $\mathrm{BA}+\mathrm{IBA}$ & $2+0.5$ & $\mathrm{BA}+\mathrm{NAA}$ & $0+0.5$ \\
\hline \multirow[t]{2}{*}{$\mathrm{BA}+\mathrm{IBA}$} & $2+1$ & $\mathrm{BA}+\mathrm{NAA}$ & $0+1$ \\
\hline & & $\mathrm{BA}+\mathrm{NAA}$ & $0+2$ \\
\hline
\end{tabular}

\section{Rooting}

Root regeneration was defined as root emission from the newly formed bulblets. As PGRs used for bulblet regeneration could later affect the root regeneration stage, we decided to evaluate the effect of NAA only in regard to rootless bulblets regenerated in the MS medium free of PGRs. In case of the explants which showed bulblet regeneration but did not enter the rooting phase, treatments containing NAA $\left(0.1,0.5\right.$ or $\left.1 \mathrm{mg} \mathrm{L}^{-1}\right)$ in the MS medium were used for rooting.

\section{Acclimatization}

Rooted bulblets were transferred to ex vitro conditions for acclimatization (Figure 1). Considering that in vitro regenerated plants need time to adapt to natural conditions, first the in vitro bulblets were planted in small pots filled with sterilized cocopeat, and perlite $(1: 2)\left(\mathrm{v} \mathrm{v}^{-1}\right)$ and pots were covered with a lid. Afterward, plants were nourished with $1 / 2$ MS solution. A week later, lids were perforated with a gradual increase in the number of pores to allow better air circulation, so the plants could slowly adapt to the natural conditions. A month later, lids were removed, and after two weeks, healthy plants were counted.

\section{Statistical analysis method}

The present study was arranged in a completely randomized design with five replicates. Two explants were considered in each replication. Explants were two-scale and four-scale segments dissected from the bulbs with a section of the basal plate. Data were analyzed statistically with SPSS software (version 22.0). For mean comparison Duncan's multiple range test was used at $5 \%$ levels of probability. 


\section{Results}

About three weeks of cultivating four-scale explants in different PGR-treatments, they turned a little green and then turned swollen. Bulblets were regenerated between the scales, which were very small at first, but they gradually grew after two subcultures (Figure 2). Regenerated bulblets were either tubular or spiral in shape without any specific order in their shapes between PGR-treatments. Based on the statistical results, the effect of different PGR-treatments on four-scale explants in MS medium was significant at $\%$ for bulblet regeneration rate and number, and in regard to bulblet length, it was significant at $1 \%$ level. It should be noted that bulblet regeneration was not observed in two-scale explants.
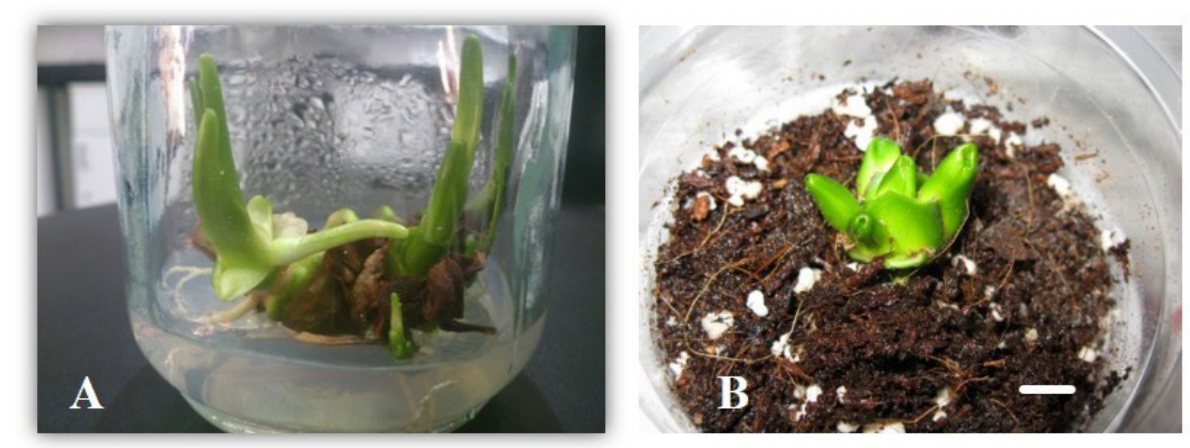

Figure 1. A) Rooted bulblet of L. aestivum before transferring to ex vitro, B) Regenerated plantlet acclimatization in a pot filled with cocopeat and perlite (scale bar $=1 \mathrm{~cm}$ )

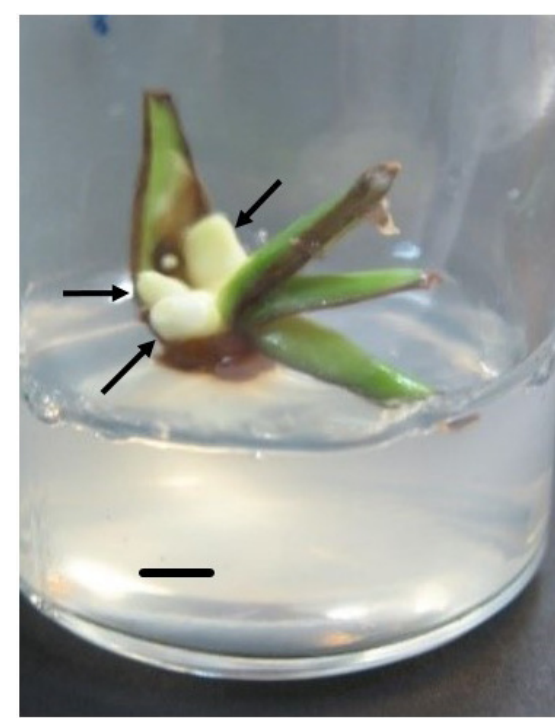

Figure 2. Bulblets regeneration from four-scale explants in the medium. Scale bar $=0.5 \mathrm{~cm}$ (Regenerated bulblets are shown by the arrows)

According to Table 3, the regeneration percentage was $90 \%$ not only in the treatments that contained 0.5 $\mathrm{mg} \mathrm{L}{ }^{-1} \mathrm{BA}$ and $0.1,0.5$ or $1 \mathrm{mg} \mathrm{L}^{-1} \mathrm{NAA}$ but also in the treatments with $1 \mathrm{mg} \mathrm{L}^{-1} \mathrm{BA}$ and 0.1 or $0.5 \mathrm{mg}$ $\mathrm{L}^{-1}$ NAA which was significantly higher than other treatments. However, in this regard, control and two other treatments had no significant difference with the mentioned treatments. While the minimum regeneration percentage $(50 \%)$, without any significant difference, belonged to the treatments of $2 \mathrm{mg} \mathrm{L}^{-1} \mathrm{BA}+0.15 \mathrm{mg} \mathrm{L}^{-1}$ $\mathrm{NAA}, 2 \mathrm{mg} \mathrm{L}^{-1} \mathrm{BA}+0.2 \mathrm{mg} \mathrm{L}^{-1} \mathrm{NAA}$ and $1 \mathrm{mg} \mathrm{L}^{-1} \mathrm{BA}+$ $1 \mathrm{mg} \mathrm{L}^{-1} \mathrm{NAA}+1 \mathrm{mg} \mathrm{L}^{-1} \mathrm{Kin}$. 
Table 3. Effect of plant growth regulators on regeneration rate, number and length of regenerated bulblets from four-scale explants.

\begin{tabular}{|c|c|c|c|c|c|c|}
\hline $\begin{array}{c}\text { PGRs treatments } \\
\left(\mathbf{m g ~ L} \mathbf{~}^{-1}\right.\end{array}$ & $\begin{array}{c}\text { Bulblet } \\
\text { regeneration } \mathbf{( \% )}\end{array}$ & $\begin{array}{c}\text { Number of } \\
\text { bulblets }\end{array}$ & $\begin{array}{c}\text { Bulblet length } \\
\mathbf{( c m})\end{array}$ & $\begin{array}{c}\text { Root } \\
\text { regeneration } \\
(\%)\end{array}$ & $\begin{array}{c}\text { Number of } \\
\text { roots }\end{array}$ & $\begin{array}{c}\text { Root length } \\
(\mathbf{c m})\end{array}$ \\
\hline control & $80 \mathrm{ab}$ & $2.2 \pm 0.8 \mathrm{ab}$ & $1.6 \pm 0.5 \mathrm{a}$ & $40 \mathrm{~cd}$ & $1.0 \pm 1.4 \mathrm{~cd}$ & $3.8 \pm 1.6 \mathrm{a}$ \\
\hline $0.5 \mathrm{BA}+0.1 \mathrm{NAA}$ & $90 \mathrm{a}$ & $1.4 \pm 0.5 \mathrm{~b}$ & $0.95 \pm 0.4 \mathrm{~b}$ & $80 \mathrm{ab}$ & $1.4 \pm 0.8 \mathrm{~cd}$ & $2.2 \pm 1.6 \mathrm{abcd}$ \\
\hline $0.5 \mathrm{BA}+0.5 \mathrm{NAA}$ & $90 \mathrm{a}$ & $2.0 \pm 0.0 \mathrm{ab}$ & $1.0 \pm 0.3 \mathrm{~b}$ & $70 \mathrm{abc}$ & $2.8 \pm 1.7 \mathrm{bc}$ & $3.4 \pm 1.8 \mathrm{a}$ \\
\hline $0.5 \mathrm{BA}+1 \mathrm{NAA}$ & $90 \mathrm{a}$ & $2.0 \pm 0.7 \mathrm{ab}$ & $0.5 \pm 0.0 \mathrm{~b}$ & $45 \mathrm{~cd}$ & $4.2 \pm 0.8 \mathrm{ab}$ & $2.6 \pm 1.1 \mathrm{abc}$ \\
\hline $1 \mathrm{BA}+0.1 \mathrm{NAA}$ & $90 \mathrm{a}$ & $1.8 \pm 0.8 \mathrm{ab}$ & $0.5 \pm 0.0 \mathrm{~b}$ & $20 \mathrm{~d}$ & $0.4 \pm 0.5 \mathrm{~d}$ & $0.4 \pm 0.5 \mathrm{~d}$ \\
\hline $1 \mathrm{BA}+0.5 \mathrm{NAA}$ & $90 \mathrm{a}$ & $2.8 \pm 1.4 \mathrm{a}$ & $0.8 \pm 0.2 \mathrm{~b}$ & $80 \mathrm{ab}$ & $4.6 \pm 2.1 \mathrm{ab}$ & $2.8 \pm 1.0 \mathrm{ab}$ \\
\hline $1 \mathrm{BA}+1 \mathrm{NAA}$ & $80 \mathrm{ab}$ & $1.2 \pm 0.4 \mathrm{~b}$ & $0.9 \pm 0.2 \mathrm{~b}$ & $90 \mathrm{a}$ & $5.4 \pm 1.6 \mathrm{a}$ & $3.4 \pm 0.8 \mathrm{a}$ \\
\hline $2 \mathrm{BA}+0.2 \mathrm{NAA}$ & $50 \mathrm{~b}$ & $1.3 \pm 0.5 \mathrm{~b}$ & $0.8 \pm 0.2 \mathrm{~b}$ & $66 \mathrm{abc}$ & $2.0 \pm 1.7 \mathrm{~cd}$ & $3.3 \pm 1.5 \mathrm{a}$ \\
\hline $2 \mathrm{BA}+0.15 \mathrm{NAA}$ & $50 \mathrm{~b}$ & $1.0 \pm 0.0 \mathrm{~b}$ & $0.5 \pm 0.0 \mathrm{~b}$ & $33 \mathrm{~d}$ & $1.0 \pm 1 \mathrm{~cd}$ & $0.6 \pm 0.5 \mathrm{~cd}$ \\
\hline $1 \mathrm{BA}+1 \mathrm{NAA}+1 \mathrm{Kin}$ & $50 \mathrm{~b}$ & $1.3 \pm 0.5 \mathrm{~b}$ & $1.0 \pm 0.5 \mathrm{~b}$ & $50 \mathrm{bcd}$ & $2.6 \pm 0.5 \mathrm{bc}$ & $1.0 \pm 0.0 \mathrm{bcd}$ \\
\hline $1 \mathrm{BA}+1 \mathrm{Kin}$ & $80 \mathrm{ab}$ & $2.6 \pm 0.5 \mathrm{a}$ & $1.6 \pm 0.2 \mathrm{a}$ & $0.0 \mathrm{e}$ & $0.0 \pm 0.0 \mathrm{e}$ & $0.0 \pm 0.0 \mathrm{e}$ \\
\hline
\end{tabular}

* Means with similar letters within each column are not significantly different at $5 \%$ level of Duncan's multiple range test. Each value represents the mean \pm SD.

The highest mean of regenerated bulblets $(2.8)$ belonged to the treatment containing $1 \mathrm{mg} \mathrm{L}^{-1} \mathrm{BA}$ and $0.5 \mathrm{mg} \mathrm{L}^{-1}$ NAA without any significant difference compared to the control and four other treatments. Effect of different PGRtreatments on bulblet length demonstrated that the highest average of bulblet length $(1.6 \mathrm{~cm})$ was achieved from the control medium and the medium fortified with $1 \mathrm{mg} \mathrm{L}^{-1} \mathrm{BA}$ $+1 \mathrm{mg} \mathrm{L}^{-1} \mathrm{Kin}$, as well.

Explants cultured in PGR-treatments for bulblet regeneration initiated roots as well as bulblets almost simultaneously. Effect of these treatments on root regeneration, number of the roots and their lengths was significant at $1 \%$ level. Based on Table 3, the highest mean percentage of root regeneration $(90 \%)$ belonged to the treatment with $1 \mathrm{mg} \mathrm{L}^{-1} \mathrm{BA}+1 \mathrm{mg} \mathrm{L}^{-1} \mathrm{NAA}$, while treatment with $1 \mathrm{mg} \mathrm{L} \mathrm{L}^{-1} \mathrm{BA}+1 \mathrm{mg} \mathrm{L^{-1 }} \mathrm{Kin}$ had no root regeneration. Among the rest of treatments with signs of root regeneration, the minimum regeneration percentage (20\%) belonged to the treatment with $1 \mathrm{mg} \mathrm{L}^{-1} \mathrm{BA}+0.1 \mathrm{mg}$ $\mathrm{L}^{-1}$ NAA. Effect of different PGRs treatments on the root number demonstrated that the highest mean of root numbers (5.4) belonged to the medium fortified with $1 \mathrm{mg} \mathrm{L}^{-1} \mathrm{BA}+$ $1 \mathrm{mg} \mathrm{L}^{-1} \mathrm{NAA}$, with a significant statistical difference with other treatments. The highest mean of root length $(3.8 \mathrm{~cm})$ belonged to the control treatment without any significant difference with a number of other treatments.

Two months after culturing four-scale explants in different PGR-treatments for callus induction, first, volume was increased, followed by the formation of greenishyellow calli with a friable type of tissue (Figure 3).

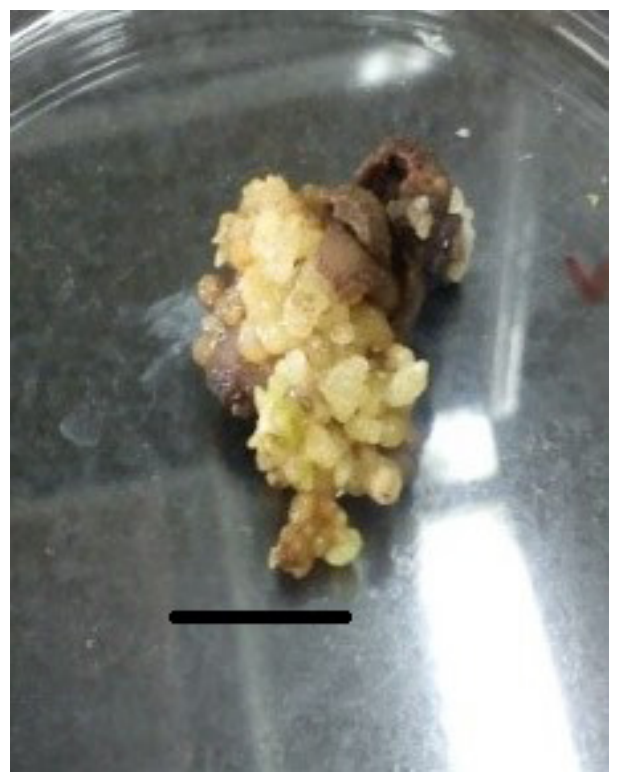

Figure 3. Callus induction from a four-scale explant. Scale bar $=1.5 \mathrm{~cm}$ 
Callus measurements were carried out at the first and second subcultures after the first signs of callus formation. ANOVA results indicated the significant effect of the PGRtreatments on callus amount of four-scale explants and the significant effect of subcultures on this trait at 5\% level. Results of the mean comparison regarding the effects of PGR-treatments on callogenesis are depicted in Figure 4. Based on this, the highest callus amount (4.5) belonged to the treatment containing $0.5 \mathrm{mg} \mathrm{L}^{-1} \mathrm{BA}$ and $5 \mathrm{mg} \mathrm{L}^{-1}$ 2,4-D. While the effects of PGRs treatments, subcultures, and their interaction were insignificant on the percentage of callogenesis. Callus induction percentage in both first and second subcultures was $100 \%$ which means that both types of explants have responded to the PGR-treatments and generated callus in the callus induction media.

Effect of subcultures on callus amount showed higher

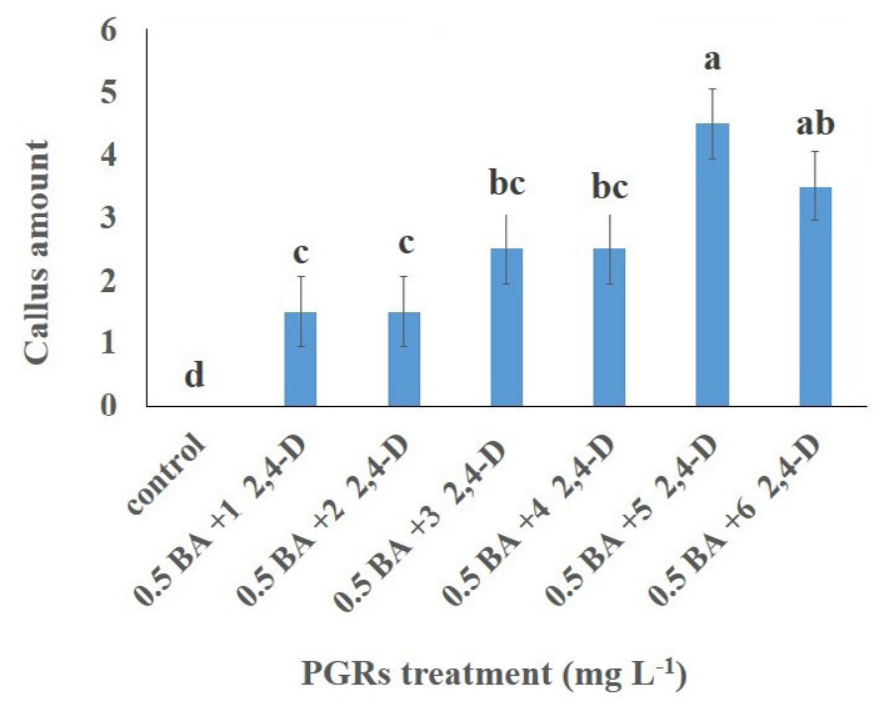

Figure 4. Effect of different PGR-treatments on in vitro callus amount initiated from four-scale explants. Means with different letters had significant differences based on Duncan's multiple range test with p-value of 5\%. Each error bar represents SE. Callus amount is shown by rating; 0: no callus, 1: very poor, 2: poor, 3: medium, 4: high, 5: profuse.

callus formation in the first subculture with a significant difference (Figure 5). However, explants turned brown after subculture and calli gradually degenerated. Nevertheless, parts of callus stayed intact in some replicates, and indirect regeneration was observed after a while. Bulblets were regenerated from callus, but due to inadequate replications in each treatment, statistical analysis of indirect regeneration was not conducted.

Root regeneration occurred simultaneously with the formation of bulblets in different treatments, but some of the explants did not enter the rooting phase. In such cases, bulblets were transferred for rooting into media containing various concentrations of NAA. Based on the ANOVA results the effect of PGR-treatments on the number and length of the roots was significant at 5\%. However, its effect was insignificant on regeneration percentage.

Results of mean comparison regarding the effects of PGR-treatments on root characteristics are shown in Table 4.

Based on the results, maximum root number (4.6)

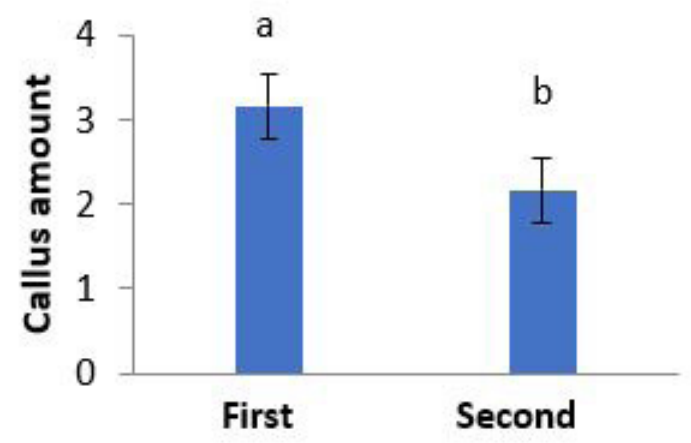

\section{Subculture}

Figure 5. Comparing the means of callus amount in the first and second subcultures. Means with different letters had significant differences based on Duncan's multiple range test with p-value of 5\%. Each error bar represents SE. Callus amount is shown by rating; 0 : no callus, 1: very poor, 2: poor, 3: medium, 4: high. 
Table 4. Effect of PGRs treatments on rooting of regenerated four-scale explants

\begin{tabular}{|c|c|c|c|}
\hline $\begin{array}{c}\text { PGRs treatments } \\
\left(\mathbf{m g ~ L}^{-\mathbf{1}}\right)\end{array}$ & $\begin{array}{c}\text { Regeneration } \\
(\mathbf{\%})\end{array}$ & Number of roots & $\begin{array}{c}\text { Root length } \\
(\mathbf{c m})\end{array}$ \\
\hline $0.1 \mathrm{NAA}$ & $50 \mathrm{a}$ & $1.3 \mathrm{~b}$ & $1.5 \mathrm{~b}$ \\
\hline $0.5 \mathrm{NAA}$ & $83.3 \mathrm{a}$ & $2.0 \mathrm{~b}$ & $6.3 \mathrm{a}$ \\
\hline $1 \mathrm{NAA}$ & $66.6 \mathrm{a}$ & $4.6 \mathrm{a}$ & $2.0 \mathrm{~b}$ \\
\hline
\end{tabular}

* Means with similar letters within each column are not significantly different at 5\% level of Duncan's multiple range test.

belonged to the treatment with $1 \mathrm{mg} \mathrm{L}^{-1} \mathrm{NAA}$ and the highest root length $(6.3 \mathrm{~cm})$ was achieved from the treatment containing $0.5 \mathrm{mg} \mathrm{L}^{-1} \mathrm{NAA}$.

\section{Discussion}

Similar to the various bulbiferous plants such as Tulips, Narcissus and Liliums, L. aestivum also contains a wide range of endophytes. The method used in this research to disinfect the explants was similar to Shahin et al. (2018) in using the water bath for controlling the contamination of scale explants of Narcissus tazetta and also using ethanol and sodium hypochlorite.

Bulblets as well as other storage organs that are produced in vitro have ideal characteristics that make them preferred propagules, such as easy handling, transportation and storage. Also, they do not require a considerable acclimatization after transfer to soil (Askari et al., 2018). Based on the results of Kohut et al. (2007) culturing bulb scales of $L$. aestivum on MS medium that contained $1 \mathrm{mg}$ $\mathrm{L}^{-1} \mathrm{BA}$ and $0.1 \mathrm{mg} \mathrm{L}^{-1} \mathrm{NAA}$ showed that $69.2 \%$ of the explants regenerated bulblets and similar to the present study, rooting occurred in the bulblets induction medium in some of the four-scale explants. Also, in terms of bulblet regeneration from four-scale explants in the control treatment, result from the current study coincides with the reports of Diop et al. (2007). It has been reported that in the Amaryllidaceae family, the existence of a basal plate as part of the explant is necessary; otherwise, no bulblets would be regenerated (Babashpour-asl et al., 2016) such as in the initiation of new bulblets in Lycoris species. A basal plate is a compressed stem surrounded by modified leaves and scales, which makes this bulblet regeneration process similar to the axillary bud initiation in monocotyledonous plant species (Ren et al., 2017).

In the present study, the presence of a larger basal plate in four-scale explants compared to two-scale explants has seemingly caused the regeneration from these explants. In a research on Galanthus transcaucasicus which belongs to the Amaryllidaceae family, Babashpour-asl et al. (2016) stated that single-scale, twin-scale and four-scale explants all showed bulblet regeneration; although, the highest regeneration percentage and maximum regenerated bulblets was achieved from four-scale explants. Whereas, in the present study, no regeneration occurred from twoscale explants that are apparently due to the difference in the studied species. As during the propagation of bulbs, the growth rate of bulblets is influenced by the nutritional reserves in the mother bulb (Kharrazi et al., 2017) and considering that in the twin scaling method, the nutritional reserves are less than in four scale explants, our achieved results might be explainable.

Callogenesis could be a beneficial experimental system for monitoring alkaloid biosynthesis (Tarakemeh et al., 2019). The effect of PGRs on callogenesis was also studied by Gomes-Copeland et al. (2020) and they reported that the type and concentration of PGRs affected the percentage of in vitro callogenesis from the explants of Crinum americanum L. (Amaryllidaceae). Corresponding to these findings, the concentrations used in our study had an influential role in callus formation, as well. Based on Table 3, considering that BA concentration was similar in all the treatments $(0.5$ $\left.\mathrm{mg} \mathrm{L}^{-1}\right)$ and 2,4-D concentration varied between 1 to $6 \mathrm{mg}$ $\mathrm{L}^{-1}$, the effective role of 2,4-D in callus induction can be mentioned. Sun at al. (2018) also stated that among NAA, IAA and 2,4-D, the latter PGR had a greater effect on callus induction in Narcissus pseudonarcissus cv. Dutch Master. Boltenkov et al. (2007) also studied three different Iris species and stated that 2, 4-D was the best auxin for induction of callus. Generally, callus induction in monocots is weaker than dicots; hence, for PGRs stimulation to form a callus, it is needed to add an auxin to encourage cell division (callus formation).

In vitro rooting efficiency in response to exogenous auxins is influenced by the quantity of endogenous auxins and the amount of free auxin available to competent cells and also the affinity of the auxin receptors that participate in rooting (Park et al., 2017). Kohut et al. (2007) reported that the best PGR treatment for rooting of L. aestivumis was $1 \mathrm{mg} \mathrm{L}^{-1} \mathrm{NAA}$. In the current study, the PGRs treatment of 1 $\mathrm{mg} \mathrm{L}^{-1} \mathrm{NAA}$ induced the most roots in rootless regenerated bulblets. It should be mentioned that in the medium devoid of PGRs, regenerated roots had a natural form, but thickened, shortened and deformed roots were regenerated in the media fortified with PGRs. Since using different levels of BA and NAA transformed the natural phenotype of the roots and considering the importance of being trueto-type in the in vitro cultures, some problems may arise in absorbing nutrients. Morphological disorders in the roots in our study might have been due to the presence of BA that quite often causes morphological and physiological disorders in plants (Tubić et al., 2016). Root disorders is more than just a morphological abnormality, since it affects the overall growth of the plant (Singh, 2018). Therefore, it is suggested to use a PGR-free culture medium for rooting. On the other hand, it should be added that although the 
application of PGRs combinations improved some traits in the current study, generally, regeneration percentage, bulblet length and numbers in the control treatment was not very different from the best regeneration treatment from the four-scale explants in each case. Therefore, in the present study the control treatment can be introduced as the most promising one; totally, and we suggest to avoid using PGRs in micropropagation of this species, which is commercially important in vast production and also costs reduction might seem reasonable. In the present experiment, approximately $90 \%$ of the plants were acclimatized, and the rest deteriorated, gradually. However, the growth rate of bulblets was very slow, and probably the plants were in dormancy due to the transplanting tension.

\section{Conclusions}

Leucojum aestivum is in need of conservation measures. Based on our findings, using four scale explants seems to be more promising than the frequently used twin scale technique for the in vitro regeneration and restoration of this species. In the current investigation the effect of different combinations and concentrations of various PGRs on micropropagation of this plant was addressed and totally, the control medium with some preferences proved to be better than the other treatments. Considering its ornamental values and medicinal properties, this study can be further continued for the higher rates of bulb propagation or production of secondary metabolites in the commercial scale.

\section{Author Contribution}

MA: carried out the experiment, wrote the manuscript with support from Sepideh kalatehjari, performed the idea, conceived and planned the development of the experiments, and was in charge of overall direction and planning. SK: helped supervise the project, performed the idea, manuscript writing, and corrections, conceived the original idea, provided critical feedback, helped shape the research, analysis, and manuscript.

\section{References}

AL-FARIS, H.D.H.; BULDUK, I.; KAHRAMAN, A. Biochemical and micro-morphoanatomical investigations on Leucojum aestivum L. Notulae Botanicae Horti Agrobotanici Cluj-Napoca, v.47, n.4, p.1382-1393, 2019. https://doi.org/10.15835/nbha47411733

ASKARI, N.; VISSER, R.G.; DE KLERK, G.J. Growth of lily bulblets in vitro, a review. International Journal of Horticultural Science and Technology, v.5, n.2, p.133143, 2018. https://doi.org/10.22059/ijhst.2018.268870.263

BABASHPOUR-ASL, M.; MOVAFEGHI, A.; ZARE, K.
In Vitro production of bulblet in Galanthus transcaucasicus Fomin, an endangered medicinal plant. Journal of Plant Physiology \& Breeding, v.6, n.2, p.1-8, 2016.

BAKIAN, M.; HASSANPOUR ASIL, M.; FARHANGI, M.; SAHRAROO, A. Study of the response of Leucojum aestivum L. bulbs collected from different regions to organic and biological fertilizers under field conditions. Journal of Medicinal Plants and By-product, v.9, n.2, p.181-191, 2020. https://doi.org/ 10.22092/jmpb.2020.127354.1132

BOGDANOVA, Y.; STOVEA, T.; YANEV, S.; PANDOVA, B.; MOLlE, E.; BURRUS, M.; STANILOVA, M. Influence of plant origin on propagation capacity and alkaloid biosynthesis during long-term in vitro cultivation of Leucojum Aestivum L. In Vitro Cellular and Developmental Biology - Plant, v.45, n.4, p.458-465, 2009. https://doi.org/10.1007/s11627-008-9178-2

BOLTENKOV, E.V.; MIRONOVA, L.N.; ZAREMBO, E.V. Effect of phytohormones on plant regeneration in callus culture of Iris ensata thumb. Biology Bulletin, v.34, n.5, p.446-450, 2007. https://doi.org/10.1134/ S1062359007050044

CARUSO, G.; GOLUBKINA, N.; TALLARITA, A.; ABDELHAMID, M.T.; SEKARA, A. Biodiversity, ecology, and secondary metabolites production of endophytic fungi associated with Amaryllidaceae crops. Agriculture, v.10, n.11, p.533, 2020. https://doi. org/10.3390/agriculture10110533

CHERNEVA, D.; DIMITROVA, M. Healing properties of Leucojum Aestivum-Bulgarian pharmacological discovery of international significance. In: Varna Medical Forum, v.5, p.200-203, 2016.

CRIŞAN, I.; VIDICAN, R.; STOIAN, V.; ŞANDOR, M.; STOIE, A. Endophytic root colonization patterns in early and mid-spring geophytes from Cluj County. Bulletin of University of Agricultural Sciences and Veterinary Medicine Cluj-Napoca. Agriculture, v.76, n.1, p.21-27, 2019. https://doi.org/10.15835/buasvmcn-agr: 2018.0025

DIOP, M.F.; HEHN, A.; PTAK, A.; CHRÉTIEN, F.; DOERPER, S.; GONTIER, E.; BOURGAUD, F.; HENRY, M.; CHAPLEUR, Y.; LAURAIN-MATTAR, D. Hairy root and tissue cultures of Leucojum aestivum L. Relationships to galanthamine content. Phytochemistry Reviews, v.6, n.1, p.137-141, 2007. https://doi.org/10.1007/s11101-0069043-z

EKİCI, B. Some geophyte plants determined in Bartın/ Turkey. Biological Diversity and Conservation, v.10, n.1, p.49-54, 2017.

EL TAHCHY, A.; BORDAGE, S.; PTAK, A.; DUPIRE, F.; 
BARRE, E.; GUILLOU, C.; HENRY, M.; CHAPLEUR, Y.; LAURAIN-MATTAR, D. Effects of sucrose and plant growth regulators on acetylcholinesterase inhibitory activity of alkaloids accumulated in shoot cultures of Amaryllidaceae. Plant Cell, Tissue and Organ Culture, v.106, n.3, p.381-390, 2011. https://doi.org/10.1007/ s11240-011-9933-7

GHEISARI, M.; MIRI, S.M. In vitro callus induction and bulblet regeneration of hyacinth (Hyacinthus orientalis L.). Plant Cell Biotechnology and Molecular Biology, v.18, n.3-4, p.145-155, 2017.

GOMES-COPELAND, K.K.; SANTOS, I.R.; TORRES, A.G.; GOMES, J.V.; DE ALMEIDA, F.T.; FAGG, C.W.; GOMES, S.M.; SILVEIRA, D.; SIMEONI, L.A. Induction of Callus in Leaf Explants of Crinum americanum L.(Amaryllidaceae). European Journal of Medicinal Plants, v.31, n.11, p.49-56, 2020. https://doi.org/10.9734/ EJMP/2020/v31i1130298.

HAZEENA, M.S.; SULEKHA, G.R. Callus induction and plantlet regeneration in Aegle marmelos (L.) Corr. using cotyledon explants. Journal of Tropical Agriculture, v.46, p.79-84, 2008.

HUNDUR, Ö.D.; IDIL, Ö.; KANDEMIR, N.; GÜL, M.; KONAR, V. Phytochemical screening and in vitro antioxidant, antimicrobial activity and DNA interaction of Leucojum aestivum. Fresenius Environmental Bulletin, v.27, p.6704-6710, 2018.

IVANOV, I.; BERKOV, S.; PAVLOV, A.; GEORGIEV, V. In sito galanthamine extraction during the cultivation of Leucojum aestivum L. shoot culture in two $\square$ phase bubble column cultivation system. Engineering in Life Sciences, v.19, n.12, p.1000-1005, 2019. https://doi.org/10.1002/ elsc. 201900106

IVANOV, I.; GEORGIEV, V.; GEORGIEV, M.; ILIEVA, M.; PAVLOV, A. Galanthamine and related alkaloids production by Leucojum aestivum L. shoot culture using a temporary immersion technology. Applied Biochemistry and Biotechnology, v.163, n.2, p.268-277, 2011. https:// doi.org/ 10.1007/s12010-010-9036-7

KAHRAMAN, Ö.; AKÇAL, A. The enlargement of Leucojum aestivum L. in different substrates under greenhouse condition. Scientific Papers-Series B, Horticulture, v.60, p.191-197, 2016.

KHARRAZI, M.; TEHRANIFAR, A.; NEMATI, H.; BAGHERI, A. Vegetative propagation of Amaryllis (Hippeastrum $\times$ johnsonii) by different cutting methods. Horticultural Science and Technology, v.35, n.3, p.373380, 2017. https://doi.org/10.12972/kjhst.20170039
R.; MIRJALILI, M.H. Effect of photoperiod and plant growth regulators on in vitro mass bulblet proliferation of Narcissus tazzeta L.(Amaryllidaceae), a potential source of galantamine. Plant Cell, Tissue and Organ Culture, v.142, p.187-199, 2020. https://doi.org/10.1007/s11240020-01853-y

KOHUT, E.; ÖRDÖGH, M.; JÁMBOR-BENCZÚR, E.; MÁTHÉ, Á. Results with the establishment of in vitro culture of Leucojum aestivum. International Journal of Horticultural Science, v.13, n.2, p.67-71, 2007. https:// doi.org/10.31421/IJHS/13/2/723

MURASHIGE, T.; SKOOG, F. A revised medium for rapid growth and bioassays with tobacco tissue culture. Physiologia Plantarum, v.15, p.473-497, 1962. https:// doi.org/10.1111/j.1399-3054.1962.tb08052.x

NAIDOO, D.; AREMU, A.O.; VAN STADEN, J.; FINNIE, J.F. In vitro plant regeneration and alleviation of physiological disorders in Scadoxus puniceus. South African Journal of Botany, v.109, p.316-322, 2017. https://dx.doi.org/10.1016/j.sajb.2017.01.010

OSENI, O.M.; PANDE, V.; NAILWAL, T.K. A review on plant tissue culture, a technique for propagation and conservation of endangered plant species. International Journal of Current Microbiology and Applied Sciences, v.7, n.7, p.3778-3786, 2018. https://doi.org/10.20546/ ijcmas.2018.707.438

PARK, S.H.; ELHITI, M.; WANG, H.; XU, A.; BROWN, D.; WANG, A. Adventitious root formation of in vitro peach shoots is regulated by auxin and ethylene. Scientia Horticulturae, v.226, p.250-260, 2017. https://dx.doi. org/10.1016/j.scienta.2017.08.053

PRIYADHARSHINI, S.; KANNAN, N.; MANOKARI, M.; SHEKHAWAT, M.S. In vitro regeneration using twin scales for restoration of critically endangered aquatic plant Crinum malabaricum Lekhak \& Yadav: a promising source of galanthamine. Plant Cell, Tissue and Organ Culture, v.141, p.593-604, 2020. https://doi.org/10.1007/s11240020-01818-1

PTAK, A. Leucojum aestivum L. in vitro bulbs induction and acclimatization. Open Life Sciences, v.9, n.11, p.10111021, 2014. https://doi.org/10.2478/s11535-014-0339-5

REIS, A.; MAGNE, K.; MASSOT, S.; TALLINI, L.R.; SCOPEL, M.; BASTIDA, J.; RATET, P.; ZUANAZZI, J.A. Amaryllidaceae alkaloids: identification and partial characterization of montanine production in Rhodophiala bifida plant. Scientific Reports, v.9, n.1, p.8471 2019. https://doi.org/10.1038/s41598-019-44746-7 
Y. Cytological analysis of the bulblet initiation and development in Lycoris species. Scientia Horticulturae, v.218, n.1, p.72-79, 2017. https://doi.org/10.1016/j. scienta.2017.02.027

RESETÁR, A.; FREYTAG, C.; KALYDI, F.; GONDA, S.; MÁRTA, M.; AJTAY, K.; PAPP, L.; MÁTHÉ, C. Production and antioxidant capacity of tissue cultures from four Amaryllidaceae species. Acta Societatis Botanicorum Poloniae, v.86, n.1, p.3525, 2017. https://doi.org/10.5586/ asbp. 3525

SALIBA, S.; PTAK, A.; BOISBRUN, M.; SPINA, R.; DUPIRE, F.; LAURAIN MATTAR, D. Stimulating effect of both 4'O methylnorbelladine feeding and temporary immersion conditions on galanthamine and lycorine production by Leucojum aestivum L. bulblets. Engineering in Life Sciences, v.16, n.8, p.731-739, 2016. https://doi. org/10.1002/elsc. 201600045

SHAHIN, H., DE KLERK, G.J.; EL-HELA, A.A. Effect of growth regulators on multiplication and alkaloid production of Narcissus Tazetta var. italicus in tissue culture. Propagation of Ornamental Plants, v.18, n.4, p.124-130, 2018.

SINGH, R. A botanical briefing on root abnormalities and non-vegetative propagation. Bulletin of Pure \& Applied Sciences-Botany, v.37, n.2, p.143-145, 2018.

SUN, X.; SUN, Q.; FEI, R.; MA, Y.; Li, X.; Yao, X.
Callus induction, differentiation and plant regeneration of Narcissus pseudonarcissus cv. Dutch Master. Journal of Shenyang Agricultural University, v.49, n.4, p.465-70, 2018.

TARAKEMEH, A.; AZIZI, M.; ROWSHAN, V.; SALEHI, H.; SPINA, R., DUPIRE, F.; AROUEI, H.; LAURAIN-MATTAR, D. Quantitative determination of Lycorine and Galanthamine in different in vitro tissues of Narcissus tazetta by GC-MS. International Journal of Horticultural Science and Technology, v.6, n.2, p.151157, 2019. https://doi.org/10.22059/ijhst.2019.280853.295

TORRAS CLAVERIA, L.; TALLINI, L.R.; VILADOMAT MEYA, F.; BASTIDA ARMENGOL, J. Research in natural products: Amaryllidaceae ornamental plants as sources of bioactive compounds V. In: Muñoz-Torrero, D.; Riu, M.; Feliu, C. Recent Advances in Pharmaceutical Sciences VII. Kelara: Research Signpost, 2017. p.69-82.

TUBIĆ, L.; SAVIĆ, J.; MITIĆ, N.; MILJEVIĆ, J.; JANOŠEVIĆ, D.; BUDIMIR, S.; ZDRAVKOVIĆKORAĆ, S. Cytokinins differentially affect regeneration, plant growth and antioxidative enzymes activity in chive (Allium schoenoprasum L.). Plant Cell, Tissue and Organ Culture, v.124, n.1, p.1-14, 2016. https://doi.org/10.1007/ s11240-015-0869-1 